\title{
Lycopene Modulates THP1 and Caco2 Cells Inflammatory State through Transcriptional and Nontranscriptional Processes
}

\author{
Njock Makon-Sébastien, ${ }^{1,2}$ Fouchier Francis, ${ }^{1}$ Seree Eric, ${ }^{3,4}$ Villard Pierre Henri, ${ }^{5}$ \\ Landrier Jean François, ${ }^{3}$ Pechere Laurent, ${ }^{6}$ Barra Yves, ${ }^{1}$ and Champion Serge ${ }^{5}$ \\ ${ }^{1}$ Laboratoire de Génie Génétique, Faculté de Pharmacie, Aix-Marseille Université, 27 boulevard Jean Moulin, 13385 Marseille, France \\ ${ }^{2}$ Advanced Diagnostics, Toronto General Research Institute, University Health Network, 101 College Street, TMDT, Rm. 3-301, \\ Toronto, ON, Canada M5G $1 L 7$ \\ ${ }^{3}$ INRA, UMR1260/1062 INSERM/AMU, Nutrition, Obésité et Risque Thrombotique, 27 boulevard Jean Moulin, 13385 Marseille, France \\ ${ }^{4}$ Laboratoire de Génie Génétique, INRA 1260, Faculté de Pharmacie, 27 boulevard Jean Moulin, 13385 Marseille Cedex 5, France \\ ${ }^{5}$ IMBE-UMR CNRS 7263/IRD 237, Mutagenèse Environnementale, Faculté de Pharmacie, Aix-Marseille Université, \\ 27 boulevard Jean Moulin, 13385 Marseille, France \\ ${ }^{6}$ Laboratoires YVERY, 134 rue Edmond Rostand, 13008 Marseille, France
}

Correspondence should be addressed to Seree Eric; seree.eric@gmail.com

Received 7 February 2014; Revised 11 April 2014; Accepted 11 April 2014; Published 7 May 2014

Academic Editor: Stefanie B. Flohé

Copyright (C) 2014 Njock Makon-Sébastien et al. This is an open access article distributed under the Creative Commons Attribution License, which permits unrestricted use, distribution, and reproduction in any medium, provided the original work is properly cited.

\begin{abstract}
We revisited the action of a carotenoid, the lycopene, on the expression of proinflammatory genes, reactive oxygen species (ROS) production, and metalloprotease (MMP9) activity. THP1 and Caco2 cell lines were used as in vitro models for the two main cell types found in intestine tissue, that is, monocytes and epithelial cells. Proinflammatory condition was induced using either phorbol ester acetate (PMA), lipopolysaccharide (LPS) or tumor necrosis factor (TNF). In THP1 cells, short term pretreatment ( $2 \mathrm{~h}$ ) with a low concentration $(2 \mu \mathrm{M})$ of lycopene reinforce proinflammatory gene expression. The extent of the effect of lycopene is dependent on the proinflammtory stimulus (PMA, LPS or TNF) used. Lycopene enhanced MMP9 secretion via a c-AMP-dependent process, and reduced ROS production at higher concentrations than $2 \mu \mathrm{M}$. Cell culture media, conditioned by PMA-treated monocytes and then transferred on CaCo-2 epithelial cells, induced a proinflammatory state in these cells. The extent of this inflammatory effect was reduced when cells has been pretreated $(12 \mathrm{~h})$ with lycopene. At low concentration $(2 \mu \mathrm{M}$ or less), lycopene appeared to promote an inflammatory state not correlated with ROS modulation. At higher concentration $(5 \mu \mathrm{M}-20 \mu \mathrm{M})$, an anti-inflammatory effect takes place as a decrease of ROS production was detected. So, both concentration and time have to be considered in order to define the exact issue of the effect of carotenoids present in meals.
\end{abstract}

\section{Introduction}

Epidemiological studies have shown that increased consumption of fruit and vegetables is associated with a lower risk of several kinds of pathologies [1-3]. Such beneficial effect could be due at least in part to the presence of carotenoids in the diet. Among carotenoids, lycopene has been particularly studied. Lycopene is a nonprovitamin A carotenoid found mainly in tomatoes and water melon. There is evidence suggesting that this compound plays a role in decreasing the occurrence of and the progression of certain cancers (prostate and hepatoma) [4-7] and several epidemiological studies have also linked high plasma lycopene concentrations to a lower risk of developing cardiovascular disease [4]. However, the mechanism underlying these effects remains unknown and there is debate over the impact of lycopene on human health [1-3].

It is well established that lycopene is able to modulate gene expression [8-12]. Several regulations have been depicted, including modulation of connexin 43 ( $\mathrm{Cx} 43)$ gene expression [13-15], inhibition of cell proliferation [15, 16], or induction of G1/S cell cycle arrest in the MCF-7 cell line by decreasing the expression of the D1 and D3 cyclins [17].

Furthermore, the properties of lycopene could rely on its transcriptional modulation of cytokine expression. It 
was notably demonstrated that lycopene and metabolites regulate cytokine expression in adipose tissue (suppress and adipocyte) [18-20]. In addition, lycopene was also suspected to act on the level of MMP9 expression [21], which is known to be involved in basal membrane degradation and this process plays a major role in inflammation $[22,23]$ and cell invasion [24].

Thus, regulation of inflammation appears as a common process connecting molecular effects of lycopene. However, only few studies have been especially devoted to this aspect in intestine, which constitute the first line of effect of micronutrients. Indeed, intestinal epithelial cells provide the first point of contact for micronutrients within the gut lumen; they also interface and segregate the gut immune system through which nutrients can trigger or modulate proinflammatory gene transcription, leading to an amplification of the inflammatory immune response $[25,26]$. The currently available data derived from, respectively, in vivo and in vitro models appeared contradictory. Indeed, in mice models, it was found that lycopene-rich extract prevented lipopolysaccharide-induced $\mathrm{NF} \kappa \mathrm{B}$ signaling [27]. It was also reported that lycopene supplementation attenuated the inflammatory status of colitis in a rat model and had a beneficial effect on the various macroscopic parameters examined including: colonic thickness, colon weight, and inflammation [28]. In contrast, it was showed that exposure of the CaCo-2 human cell line model to carotenoid had no statistical significant anti-inflammatory effect on IL-8, $\mathrm{NO}, \mathrm{COX} 2$ expression, and regulation of $\mathrm{NF} \kappa \mathrm{B}$ and MAPK activities [29].

In the present study, we investigated the effects of physiological concentration $(2 \mu \mathrm{M})$ of lycopene on monocyte and an intestine-derived epithelial cell lines, on various proinflammatory targets, that is, ROS production, transcription of cytokines, and MMP9 as well as MMP9 activities.

\section{Methods and Materials}

2.1. Materials. RPMI 1640 supplemented with Hepes and glutamine was purchased from Life Technologies (CergyPontoise, France). Foetal calf serum (FCS) ("HyClone," lot $\left.\mathrm{n}^{\circ} \mathrm{CPB} 0054\right)$ was from Perbio (Thermo scientific, Brebières, France). The bicinchoninic acid (BCA) protein assay reagent was from Pierce (Interchim, Montluçon, France). The luciferase detection kit was from Promega France (Charbonnières. France). The following compounds were from Sigma (L'Isle d'Abeau, France): phosphatebuffered saline (PBS), bovine serum albumin (BSA), phenylmethylsulfonyl fluoride (PMSF), iodoacetamide, aprotinin, leupeptin, peptatin, o-phenanthroline, DEAEdextran, 4-methyl-umbelliferyl- $\beta$-D-galactoside (MUG), phorbol myristate acétate (PMA), vitamin D3 (VD3), retinoïc acid (AR), lucigenin, lycopene, interferon $\gamma(\mathrm{IFN} \gamma)$, Tumor Necrosis Factor $\alpha(\mathrm{TNF} \alpha), \mathrm{N}$-(Cis-2-phenyl-cyclopentyl) azacyclotridecan-2-imine-hydrochloride (MDL12,330A) and E. Coli-derived lipopolysaccharide 055:B5 (LPS), isobutyl-methylxanthine (IBMX), dibutyryl cyclic AMP (dbcAMP), and Forskolin (FSK). cAMP enzyme immunoassay detection kit was from "Assay Designs" (Stressgen, Euromedex, Strasbourg, France). The rabbit antiactive extracellular signal-regulated protein kinase (ERK) was from Promega France (Charbonnières, France).

\subsection{Preparation of Lycopene Encapsulated in Gelatin Particles.}

Encapsulation of lycopene in gelatin particles was carried out according to the method described by Auweter [30]. Preliminary assays have demonstrated that this preparation displayed a better biological activity (x2) compared to lycopene dissolved in solvent. Biodisponibility of the lycopene encapsulated in gelatin was evaluated in vitro using Caco 2 cells cultured on transfilter (Millicell, Millipore Corporation) and assessment of the transport of lycopene through the epithelial cells monolayer by spectrophotometric measurement of lycopene in the basal compartment. We found an enhancement of around 4 times of the biodisponibility of encapsulated lycopene compared to lycopene dissolved in solvent such as THF or DMSO. We found also over one year at $4^{\circ} \mathrm{C}$ a high stability of the dessicated and encapsulated product as indicated by spectrophotometry.

Bioactivity and biodisponibility of encapsulated lycopene were also compared to nanoemulsions of lycopene prepared using a mixture of Compritol ATo 888/Polysorbate 80/Soya lecithin. As such emulsion gives comparable results to lycopene encapsulated in gelatin and as gelatin appeared as a more neutral material than component used in emulsion, we decided to carry out all experiments with lycopene encapsulated in gelatin.

Lycopene-free gelatin particules were used as a control.

2.3. Cell Culture and Treatment. The intestinal epithelial Caco2 and the monocytic THP-1 human cell lines were routinely cultured in, respectively, DMEM and RPMI 1640 containing $2 \mathrm{mM}$ glutamine, $50 \mathrm{U} / \mathrm{mL}$ penicillin, and $50 \mu \mathrm{g} / \mathrm{mL}$ streptomycin and supplemented with $10 \%(\mathrm{v} / \mathrm{v}) \mathrm{FCS}$ at $37^{\circ} \mathrm{C}$ in $5 \% \mathrm{CO}_{2}$ atmosphere. The viability of cells was assessed by Trypan blue exclusion. In all the experiments, cells were used at a density of $1 \times 10^{6}$ cells $/ \mathrm{mL}$.

Before the stimulation, cells were cultured for $2 \mathrm{~h}$ in the absence of FCS in a BSA-supplemented medium $(0.2 \%)$ and, according to assays, with or without lycopene $(2 \mu \mathrm{M})$. Appropriate controls containing lycopene-free gelatin particles were carried out. Following this pretreatment, the cells were washed and a new identical medium supplemented or not with carotenoids was added with appropriate stimulator (PMA, $0.1 \mu \mathrm{M}$; LPS $0.1 \mu \mathrm{g} / \mathrm{mL}$; TNF $\alpha, 10 \mathrm{ng} / \mathrm{mL}$ ). The culture was resumed for $6 \mathrm{~h}$ and the cells were recovered, washed, and placed at $-80^{\circ} \mathrm{C}$. mRNA expression was analyzed by RTQPCR.

2.4. Plasmids. The regulatory sequences harbouring AP1binding sequence and $\mathrm{NF} \kappa \mathrm{B}$-binding sequence were derived from, respectively, the MMP9 (kindly supplied by Dr. Boyd) $[31,32]$ and IL-8 and IgK gene enhancer regions which have been already described [33-36]. These regulatory sequences were introduced in pGL2-based plasmids (Promega) bearing an intrinsic promoter and the luciferase reporter gene. 
2.5. Cell Transfection and Stimulation. THP1 cells were transiently transfected using DEAE-dextran-based method according to Aneja et al. [26] in STBS buffer (25 mM Tris$\mathrm{HCl}, \mathrm{pH} 7.4,137 \mathrm{mM} \mathrm{NaCl}, 5 \mathrm{mM} \mathrm{KCl}, 0.6 \mathrm{mM} \mathrm{Na}_{2} \mathrm{HPO}_{4}$, $0.7 \mathrm{mM} \mathrm{CaCl}_{2}$, and $0.5 \mathrm{mM} \mathrm{MgCl}_{2}$ ).

A total of $25 \times 10^{6}$ cells were cotransfected for $20 \mathrm{~min}$ in $0.5 \mathrm{~mL}$ STBS containing $200 \mu \mathrm{g}$ DEAE- dextran and $0.5 \mu \mathrm{g}$ plasmid to be tested together with $0.5 \mu \mathrm{g}$ of the $\mathrm{pCMV}$ plasmid expressing $\beta$-galactosidase under the control of the CMV promoter (pCMV- $\beta$-gal). Then the cells were washed, resuspended in $12 \mathrm{~mL} \mathrm{RPMI} / 10 \%$ FCS, and incubated for $24 \mathrm{~h}$. For assays, the cells were washed and resuspended in $25 \mathrm{~mL} \mathrm{RPMI} / 0,2 \% \mathrm{BSA}$ and distributed in 6-well plates ( $2 \mathrm{~mL} /$ well). Then, according to assays, lycopene $(2 \mu \mathrm{M})$ was added and $2 \mathrm{~h}$ after other agonists (TNF $\alpha, 10 \mathrm{ng} / \mathrm{mL}$ or PMA, $0.1 \mu \mathrm{M})$ to be tested. Incubation resumed for indicated time. Cell extracts were performed using the luciferase kit lysing buffer (Promega) following the manufacturer's instructions, and protein content was determined using the micro BCA reagent.

2.6. $\beta$-Galactosidase Assay. $\beta$-galactosidase activity was determined using the 4-methyl-umbelliferyl- $\beta$-D-galactoside (MUG). Each sample (30 $\mu$ g proteins) was incubated for 1 hour at $37^{\circ} \mathrm{C}$ in a reaction mixture $(100 \mu \mathrm{L})$ containing $6 \mathrm{mM}$ $\mathrm{Na}_{2} \mathrm{HPO}_{4}, 4 \mathrm{mM} \mathrm{NaH} \mathrm{PO}_{4}, 10 \mathrm{mM} \mathrm{KCl}, 0.1 \mathrm{mM} \mathrm{MgSO}$, $50 \mathrm{mM} \beta$-mercaptoethanol, and $0.5 \mathrm{mM}$ MUG, $\mathrm{pH}$ 7. The reaction was stopped by adding $400 \mu \mathrm{L}$ of $100 \mathrm{mM}$ glycine $\mathrm{pH}$ 11. Fluorescence of the product was recorded using a Perkin Elmer fluorometer, setting excitation light at $360 \mathrm{~nm}$ and emission at $446 \mathrm{~nm}$. Values of the $\beta$-galactosidase-induced fluorescence were used to normalize the luciferase activity for transfection efficiency.

2.7. Luciferase Assay. Luciferase assays were performed using $30 \mu \mathrm{g}$ proteins of the cell extracts with the luciferase assay reagent, according to the instructions of the manufacturer (Promega) and using a luminometer (Berthold, France SAS). Results were reported as arbitrary light units of luciferase normalized relatively to the $\beta$-galactosidase activity.

For transfection, each assay was performed in triplicate. Total experiments were repeated twice at least and results from a representative experiment were shown.

2.8. RNA Extraction and Real-Time PCR. Total RNA was isolated from the cells using Trizol reagent (Invitrogen, France). RNA content was quantified by optical density measurement at $260 \mathrm{~nm}$ using NanoDrop device (NanoDrop technologies Inc., France). $4 \mu \mathrm{g}$ of RNA was reverse-transcribed into cDNA using Moloney virus-derived reverse transcriptase (Invitrogen, Cergy-Pontoise, France) and random primers at $42^{\circ} \mathrm{C}$ for $1 \mathrm{~h}$. The expression of target genes was determined using the Stratagene System (MX3005P) (Stratagene, France). PCR was performed with $0.5 \mu \mathrm{M}$ of each primer, $0.5 \mu \mathrm{M}$ of the gene specific UPL Probe (Roche), and the LightCycler Taqman and 5X Master MIX Plus (Roche), in a total volume of $10 \mu \mathrm{L}$. Cycling conditions were as follows: $2 \mathrm{~min}$ at $40^{\circ} \mathrm{C}$, $10 \mathrm{~min}$ denaturing at $95^{\circ} \mathrm{C}$, followed by 40 cycles of $10 \mathrm{~s}$ denaturing at $95^{\circ} \mathrm{C}, 30 \mathrm{~s}$ primer annealing at $60^{\circ} \mathrm{C}$, and $10 \mathrm{~s}$ fragment elongation at $72^{\circ} \mathrm{C}$. The melting curve was analyzed with the LightCycler 480 and MXPRO gene scanning softwares. Human interleukin-1 $\beta$ (IL-1 $\beta$ ), interleukin8 (IL-8), intercellular adhesion molecule-1 (ICAM-1), and metalloprotease-9 (MMP-9) expressions were normalized to $\beta 2$-microglobulin expression and data quantified by the method of $2^{-\Delta \Delta \mathrm{Ct}}$ [37]. The primers used are listed in Table 1.

2.9. Preparation of Conditioned Medium (CM) Derived from PMA-Treated THP1 Cells and Assay on Caco2 Cells. In order to study the cross talk between inflammatory cells (THP1) and intestinal cells (CaCo-2), THP1 conditioned medium (CM) was prepared. THP1 cells were exposed or not to PMA for 2 hours. The medium was then discarded and the cells were extensively washed. Fresh medium without PMA was added for an additional $6 \mathrm{~h}$ incubation. At the end of this incubation, the media conditioned by THP1 cells were collected and then added for $6 \mathrm{~h}$ to Caco 2 cell cultures pretreated or not with lycopene for $12 \mathrm{~h}$. The expression of inflammatory genes was assessed on these cell cultures.

2.10. Assay for Lycopene-Mediated Increase in cAMP Production. Cultured cells were washed with prewarmed PBS and resuspended with cell suspension media (RPMI 1640 containing $50 \mathrm{mM}$ HEPES, $\mathrm{pH} 7.4)$ at $37^{\circ} \mathrm{C}$. Cells were pretreated with PDE inhibitor $(50 \mu \mathrm{M}$ IBMX) for $15 \mathrm{~min}$ and then treated for different times (from 5 to $30 \mathrm{~min}$ ) with lycopene $(2 \mu \mathrm{M})$ as indicated. Treatments were terminated by addition of $1 \mathrm{~N} \mathrm{HCl}(0.1 \mathrm{~N} \mathrm{HCl}$ final). Total cAMP (intra- and extracellular) was detected by enzyme immunoassay. Data represent mean \pm SD with $n=8$.

2.11. Zymography. THP1 cells were incubated for $12 \mathrm{~h}$ in the serum-free medium supplemented or not with lycopene and other compounds to be tested. The medium was then recovered and clarified by centrifugation (3000 g, $15 \mathrm{~min}$ ) and tested by zymography for proteolytic activity.

Zymography was performed using 10\% PAGE containing gelatin $(1 \mathrm{mg} / \mathrm{mL})$. Conditioned medium was loaded on the gel $(5-20 \mu \mathrm{L})$ and migration was performed at $4^{\circ} \mathrm{C}$ for $2 \mathrm{~h}$, $15 \mathrm{~min}$ at 120 volts. After electrophoresis, gels were washed twice in buffer containing $(50 \mathrm{mM}$ Tris, $\mathrm{pH} 7.5 ; 0.15 \mathrm{M} \mathrm{NaCl}$; $2.5 \%$ Triton X100) for $30 \mathrm{~min}$ to remove SDS. Proteolytic activity was revealed by incubation of the gel in the same buffer without Triton but supplemented with appropriate concentrations of cations ( $5 \mathrm{mM} \mathrm{Ca}^{2+}, 0.5 \mathrm{mM} \mathrm{Mn}^{2+}$ ). After fixation and coloration (Coomassie blue), enzyme activity was identified as clear bands against the blue background. Gel was scanned and the digitized picture was further contrasted using PaintShop Pro software. Cell treatment and zymography were repeated at least three times and results from a representative experiment were shown.

2.12. ROS Determination. The ability of lycopene to modify ROS production was tested on macrophages-derived THP1 cells treated with PMA and was recorded by lucigenininduced luminescence. 
TABLE 1: Sequence of “UPL” primers used for RT-qPCR.

\begin{tabular}{|c|c|c|c|}
\hline Genes & Forward sequence $\left(5^{\prime}-3^{\prime}\right)$ & Reverse sequence $\left(5^{\prime}-3^{\prime}\right)$ & UPL Probe $n^{\circ}$ \\
\hline ICAM & $5^{\prime}$-CCTTCCTCACCGTGTACTGG-3' & $5^{\prime}$-AGCGTAGGGTAAGGTTCTTGC-3' & Number 71 \\
\hline IL-8 & $5^{\prime}$-AGACAGCAGAGCACACAAGC-3' & 5'-ATGGTTCCTTCCGGTGGT-3' & Number 72 \\
\hline $\operatorname{TGF} \beta$ & 5'-CCGGATACTCACGCCAGA-3' & $5^{\prime}$-AGAGATACGCAGGTGCAGGT-3' & Number 28 \\
\hline $\mathrm{TNF} \alpha$ & 5'-CAGCСТCTTCTCCTTCCTGA-3' & $5^{\prime}$-GCCAGAGGGCTGATTAGAGA-3' & Number 29 \\
\hline MMP9 & $5^{\prime}$-TGTACCGCTATGGTTACACTCG-3' & $5^{\prime}$-GCCCCAGAGATTTCGACTC- $3^{\prime}$ & Number 53 \\
\hline IL-1 $\beta$ & 5'-AACAGGCTGCTCTGGGATT-3' & $5^{\prime}$-TGGCTGCTTCAGACACTTGA- $3^{\prime}$ & Number 41 \\
\hline$\beta 2$-microgl & $5^{\prime}$-TTCTGGCCTGGAGGCTATC-3' & 5'-TCAGGAAATTTGACTTTCCATTC-3' & Number 42 \\
\hline
\end{tabular}

Differentiation of THP1 cells was carried out by supplementation of the culture medium with $\mathrm{AR}(1 \mu \mathrm{M}), \mathrm{VD} 3$ $(0.1 \mu \mathrm{M})$, and IFN $\gamma(10 \mathrm{U} / \mathrm{mL}=5 \mathrm{ng} / \mathrm{mL})$ for $48 \mathrm{~h}$. Obtained macrophages were or not treated with lycopene $(0.5-20 \mu \mathrm{M})$ during 6 hours and cell monolayer was scratched and suspended in a RPMI-based medium without phenol red supplemented with FCS (10\%). Then, the suspension was distributed in an opaque 96 -well plate $\left(200 \mu \mathrm{L}\right.$ in each well- $0.7 \times 10^{5}$ cells). Lucigenin solution $(25 \mu \mathrm{L})$ (51 mg lucigenin, $476 \mathrm{mg}$ Hepes, and $100 \mathrm{mg}$ gelatin/100 mL RPMI) and, according to assays, PMA (200 nM final concentration, $25 \mu \mathrm{L}$ ) was added. Three assays were carried out for each condition tested.

Luminescence was immediately recorded in the "luminoscan" system. Intensity values of luminescence were recorded each $5 \mathrm{~min}$ during a total period of $60 \mathrm{~min}$. Graphs were constructed and integration of curves was carried out using the excel software. Values were plotted as relative units.

2.13. Statistical Analysis. Statistical analysis was performed using GraphPad Prism Software. Mean \pm SD and intergroup comparisons were, respectively, obtained with ANOVA and Tukey's test. Values were considered statistically different when $P<0.05$. Results are presented as means \pm SD.

\section{Results and Discussion}

\subsection{Results}

3.1.1. Lycopene Modulates Proinflammatory Cytokine Expression in THP-1. The modulation of expression of several genes linked to inflammation (ICAM-1, IL-1 $\beta$, IL-8, and MMP9) was studied on THP1 cell cultures (Figure 1).

Lycopene enhanced the basal expression of proinflammatory genes, ICAM-1, IL- $1 \beta$, and IL-8, and further enhanced the LPS-induced gene expression (Figures 1(a), 1(b), and 1(c)). MMP9 gene expression was only slightly modified in the presence of lycopene (Figure 1(d)). Preliminary assays have shown that the lycopene concentration used in this report $(2 \mu \mathrm{M})$ was the lower one displaying an efficient activity on gene transcription with no effect on ROS production.

The same type of experiment was conducted with PMA as inflammatory stimulating molecule. Incubation of THP1 cells with PMA strongly enhanced the expression of inflammatory gene (Figures 2(a), 2(b), 2(c), and 2(d)). The PMA-induced enhancement of gene expression was reduced by around $30 \%$ in cells pretreated $2 \mathrm{~h}$ with lycopene (Figure 2 ). In contrast to LPS, PMA induced strongly MMP9 expression, and this enhancement was slightly reduced in cells pretreated with lycopene (Figure 2(d)).

Finally, $\mathrm{TNF} \alpha$, a third proinflammatory molecule used, upregulated gene expression of ICAM1, IL-1 $\beta$, and IL- 8 , and lycopene enhanced this effect (Figures 2(e), 2(f), and 2(g)).

These data suggested that the change in cytokine gene expression induced by lycopene was gene dependent but was also dependent on the nature of the proinflammatory stimulus (PMA, LPS, or TNF $\alpha$ ).

\subsubsection{Lycopene Modulates NFאB and AP-1 Transactivation} in THP-1. The possible lycopene-induced modulation of transcriptional response to cytokine was tested using reporter gene assay. Due to the induced high mortality in the transfected THP1 cells after LPS treatment, we used TNF $\alpha$ and PMA as stimuli to enhance gene reporter expression in transfected THP1 cells since these proinflammatory molecules did not induce apoptosis in the transfected cells (data not shown).

Reporter gene assays (Figures 3(a) and 3(b)) showed that the lycopene-induced enhancement of cytokine-stimulated gene expression involved $\mathrm{NF} \kappa \mathrm{B}$-binding sites. Indeed, in the assays, reporter gene was driven by promoter/enhancer sequence derived from both IgK and IL-8 genes which include at least one NF $\kappa \mathrm{B}$-response element. TNF $\alpha$ stimulated reporter gene expression was enhanced with $2 \mu \mathrm{M}$ lycopene (Figures 3(a) and 3(b)), whereas higher concentrations ( 4 and $10 \mu \mathrm{M}$ ) were ineffective compared to TNF $\alpha$ (Figure 3(a)). Reporter gene placed under the control of AP1 (PK3-CAT plasmid contains three AP1-binding sites but no $\mathrm{NF} \kappa \mathrm{B}$-binding site) was responsive to PMA and lycopene displayed a positive effect on this response only at $15 \mu \mathrm{M}$ (Figure 3(c)).

3.1.3. ROS Are Not Involved in the Regulation of Cytokine Expression. We investigated the contribution of antioxidant effect of lycopene in the depicted regulation. The transcriptional effects of lycopene appeared not to be linked to its antioxidant properties. Indeed, as tested by luminescence on THP1-derived macrophages recording, only lycopene concentrations above $5 \mu \mathrm{M}$ were effective in reducing PMAinduced ROS production (Figures 4(a) and 4(b)).

3.1.4. Lycopene-Induced Cytokine Expression and Modulation in Caco2 Cells. It is well known that the cytokine expression 


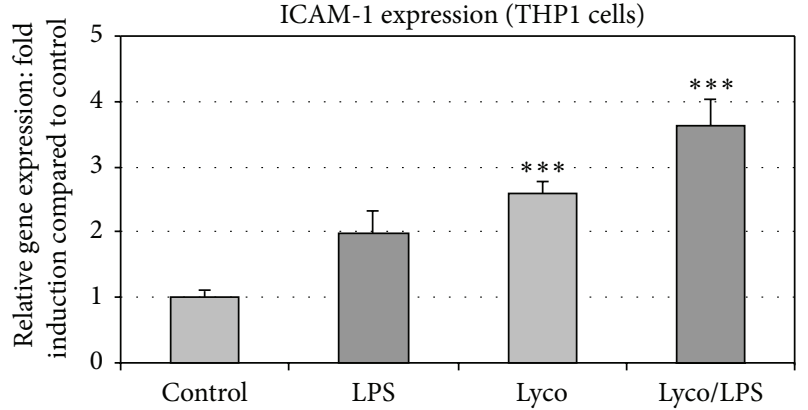

(a)

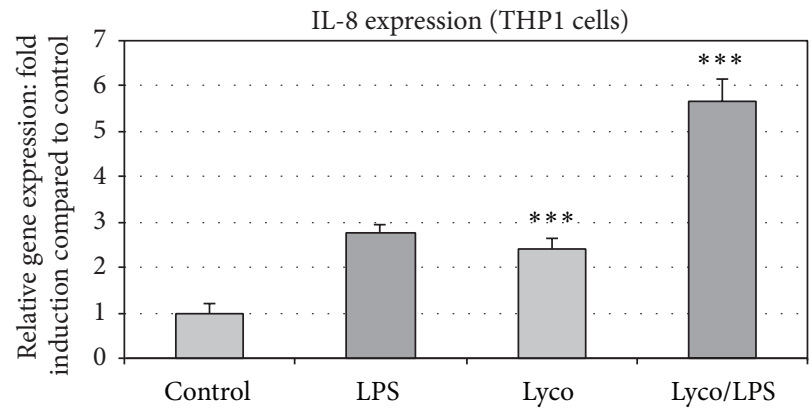

(c)

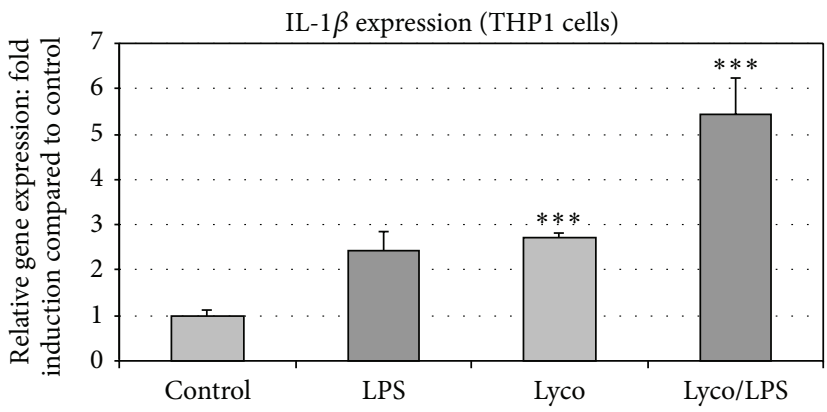

(b)

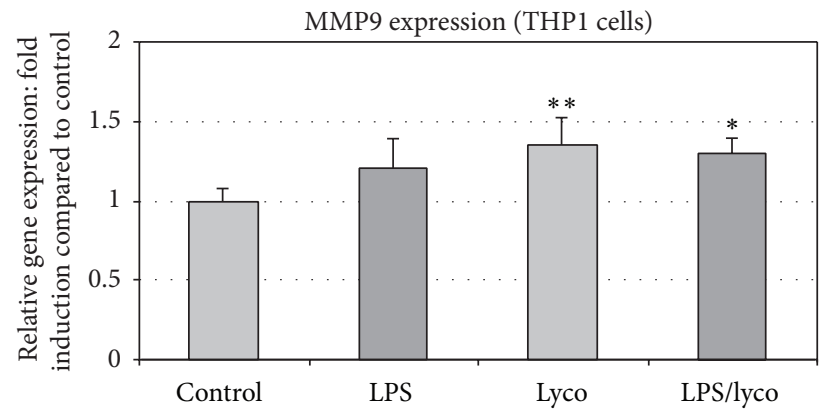

(d)

FIGURE 1: Lycopene modulates basal and LPS-induced inflammatory gene expressions in THP1 cells. ICAM-1 (a), IL-1 $\beta$ (b), IL-8 (c), and MMP9 (d) gene expression was studied in THP1 cells treated with LPS. Modulation of this expression was studied in THP1 cell cultures pretreated for $2 \mathrm{~h}$ with or without lycopene $(2 \mu \mathrm{M})$. Then, according to assays, LPS $(100 \mathrm{ng} / \mathrm{mL})$ was added for $6 \mathrm{~h}$ and mRNA expression was analyzed by RT-qPCR. Values are means \pm SD $(n=8)$. Assays treated with lycopene were compared to corresponding assays without lycopene. ${ }^{* * *} P<0.01 ;{ }^{* *} P<0.05 ; *$, nonsignificantly different.

and inflammatory gene expression, in general, are upregulated in intestinal epithelial cells in response to various inflammatory signals [25]. In agreement, IL-8 expression was induced in Caco2 cells in response to LPS (Figure 5(a)). This expression was enhanced by lycopene, and lycopene alone also induced IL-8 expression (Figure 5(a)).

To study the possible transfer of inflammatory signals from monocytes/macrophages to epithelial cells, THP1 cellderived conditioned media (CM) were prepared and tested on Caco 2 cells pretreated or not with lycopene for $12 \mathrm{~h}$, as described under materials and methods. The expression of inflammatory genes was assessed on these cell cultures.

In order to study the cross talk between inflammatory cells (THP1) and intestinal cells (CaCo-2), THP1 conditioned medium (CM) was used. This medium induced a marked enhancement of both IL- $1 \beta$ and IL- 8 productions in Caco 2 cells (Figures 5(b) and 5(c)). The IL- $1 \beta$ but not IL- 8 enhancement was strongly reduced (by around 50\%) in the lycopenepretreated $\mathrm{Caco} 2$ cells.

3.1.5. Lycopene Modulates MMP9 Activity via c-AMP. Lycopene enhanced the MMP9 activity in THP1-derived conditioned medium (Figures 6(a), 6(b), 6(c), and 6(d)). This effect did not appear to be dependent on an upregulation of gene transcription. Indeed, as reported above (Figure 1), and in contrast with an increase in enzymatic activity, lycopene did not trigger an enhancement of either basal or PMA-induced MMP9 mRNA expression in THP1 cells.

We next investigated the molecular basis of the lycopene-induced enhancement of MMP9 activity. The lycopene-induced enhancement of MMP9 gene transcription (Figure 2(d)) is significant but the effect appeared rather scarce compared to the enhancement of MMP9 enzyme activity (Figure 6). So we hypothesize that a posttranslational mechanism could be the main cause of the lycopene-induced enhancement of MMP9 activity. It has long been established that c-AMP is a regulator of various secretion processes, so we hypothesize that c-AMP may be involved in the lycopene-induced enhancement of MMP9 activity. Indeed, we found that the MMP9 secretion was upregulated by a range of compounds known to enhance the intracellular c-AMP concentrations; addition of forskolin (FSK) or dbcAMP to THP1 cell cultures treated or not with lycopene enhanced the activity of conditioned media-derived MMP9 (Figures 6(a) and 6(c)). These compounds did not modify MMP9 mRNA expression (data not shown). Furthermore, MDL-12,330A (MDL) which is known as a specific adenylate cyclase inhibitor, strongly reduced both basal and lycopene-enhanced MMP9 secretions (Figures 6(a), 6(b), 6(c), and 6(d)) and a low concentration of lycopene $(2 \mu \mathrm{M})$ induced a time-dependent enhancement of c-AMP production in IBMX-pretreated THP1 cells (Figure 7). 


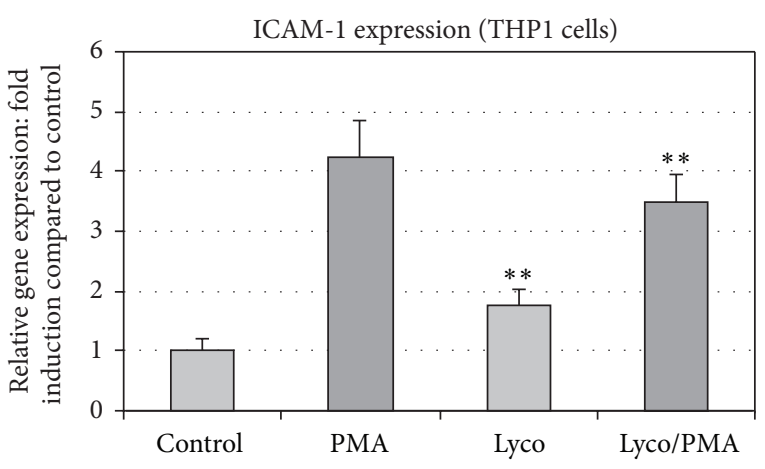

(a)

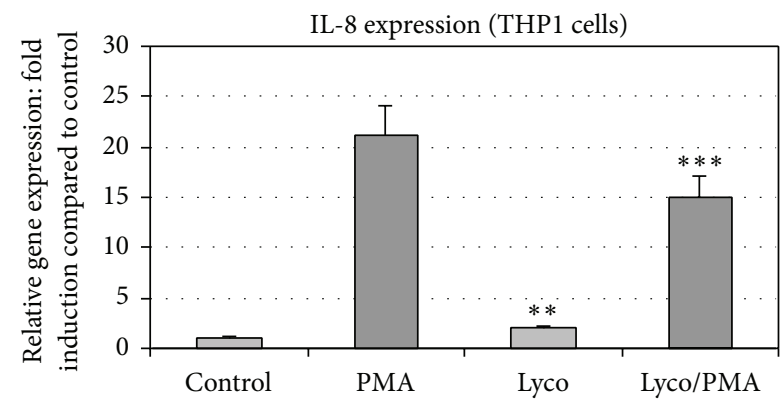

(c)

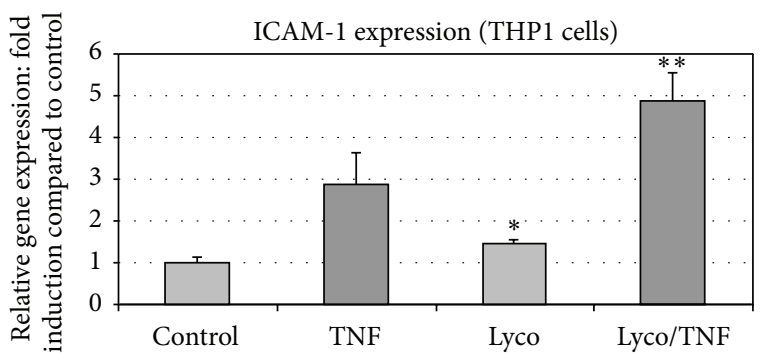

(e)

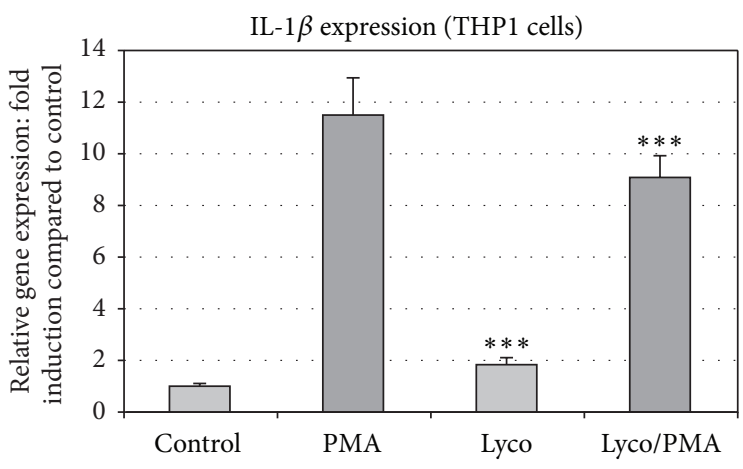

(b)

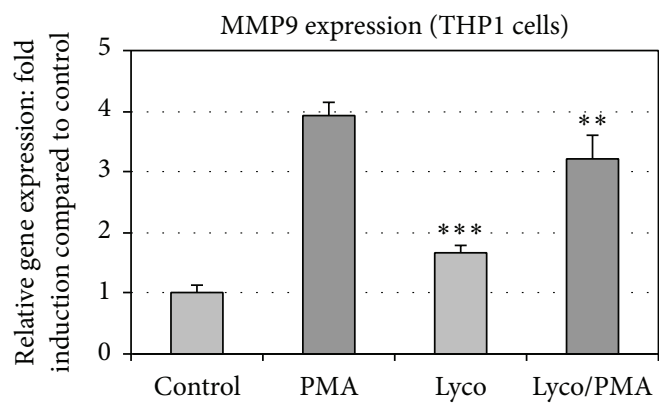

(d)

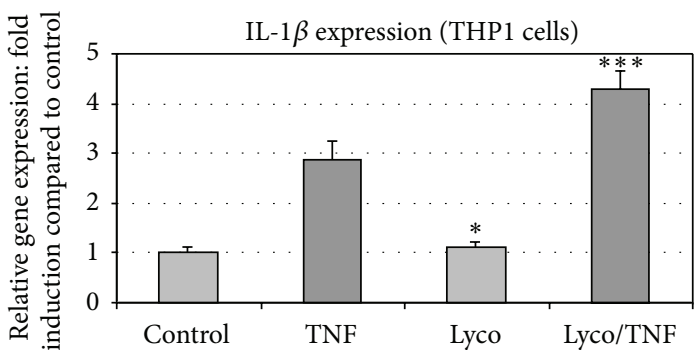

(f)

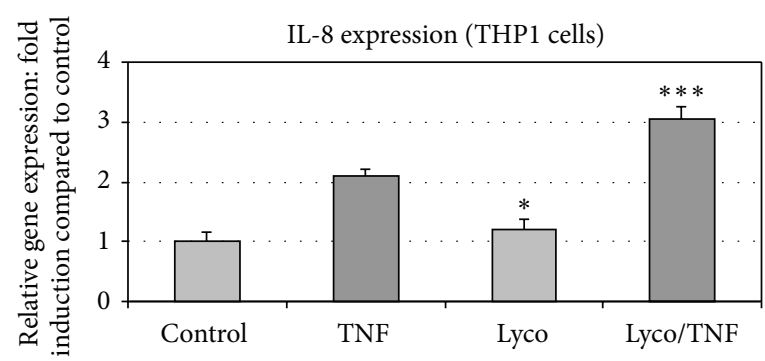

(g)

FIGURE 2: Lycopene modulates gene expression induced by PMA and TNF in THP1 cells. ICAM-1 ((a), (e)), IL-1 $\beta$ ((b), (f)), IL-8 ((c), (g)), and MMP9 (d) gene expression was studied in THP1 cells treated with either PMA (a,b,c, and d) or TNF $\alpha$ ((e), (f), and (g)). Modulation of this expression was studied in THP1 cell cultures pretreated for $2 \mathrm{~h}$ with or without Lycopene $(2 \mu \mathrm{M})$. Then, according to assays, PMA (100 nM) or TNF $\alpha(10 \mathrm{ng} / \mathrm{mL})$ was added for $6 \mathrm{~h}$ and mRNA expression was analyzed by RT-qPCR. Values are means $\pm \mathrm{SD}(n=8)$. Assays treated with lycopene were compared to corresponding assays without lycopene. ${ }^{* * *} P<0.01$; ${ }^{* *} P<0.05$; $*$, nonsignificantly different.

3.2. Discussion. In the present study we reported the effect of lycopene on the expression of genes involved in inflammation, in intestinal epithelial cells and monocytes in culture. To this purpose, the effect of lycopene was studied in vitro using Caco 2 and THP1 cells. In addition, interactions between intestinal epithelial and immune cells were envisioned through experiments involving conditioned medium.

Considering the expressions of IL- $1 \beta$, ICAM, and IL-8, we found that, according to the kind of the cell and stimulus, a low concentration of lycopene induced two opposite 


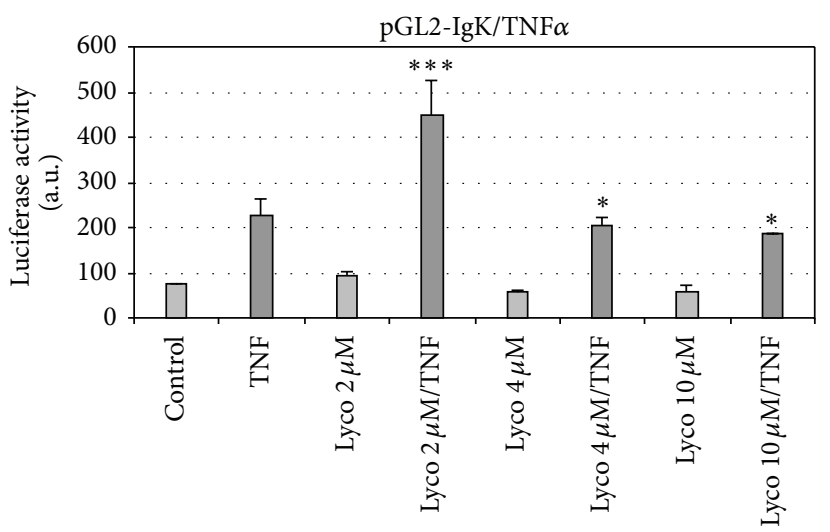

(a)

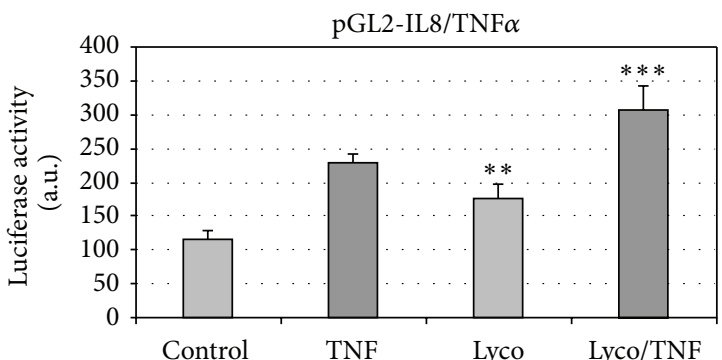

(b)

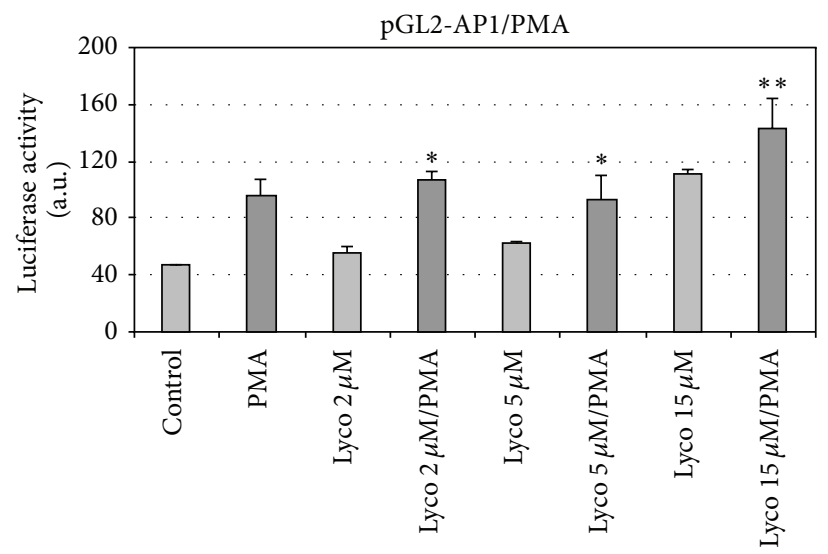

(c)

FIGURE 3: Modulation by lycopene of reporter gene activity in THP1 cells. THP1 cells were transfected using one of the luciferase reporter genes controlled by the promoter/enhancer sequence derived from either the IgK gene (pGL2-IgK-luc) (a) or the IL-8 gene (pGL2-IL-8-luc) (b). The plasmid pGL2-AP1-luc (c) contains the AP1 specific sequence. After $12 \mathrm{~h}$ transfection, cells were washed and fresh medium with or without lycopene at the indicated concentration was added, and culture continued for $2 \mathrm{~h}$. Then, according to assays, TNF $\alpha$ ((a), (b)) or PMA (c) was added and culture was resumed for $6 \mathrm{~h}$. Cells were harvested, lysed, and placed at $-80^{\circ} \mathrm{C}$. Luciferase activity was recorded. Values are means $\pm \mathrm{SD}(n=8)$. Assays treated with lycopene were compared to corresponding assays without lycopene. ${ }^{* * *} P<0.01 ;{ }^{* *} P<0.05 ; *$, nonsignificantly different.

effects on gene expression. We observed an acute and direct upregulation of either basal or LPS- and TNF $\alpha$-stimulated levels in THP1 cells but a downregulation of the PMAenhanced expression of these genes. On epithelial Caco 2 cells stimulated by a conditioned medium, lycopene induced also a dowregulation on IL1 $\alpha$ expression but had no effect on IL8 expression. These results suggested that there are at least two different targets for the lycopene at the gene regulation level, leading to either enhanced or decreased expression of the proinflammatory genes.

Present results on both gene and ROS expressions let us exclude a possible mechanism of control of gene expression triggered by low concentration of lycopene involving a modification of ROS production. Indeed, such a low concentration of lycopene did not modify ROS production in THP1derived macrophages and consequently it appears that, at least in short term cell incubation and only considering this low lycopene concentration, ROS were not involved in the lycopene-induced gene regulation.
The pathway involving ROS has been suggested to be an important process involved in some but not all carotenoid-induced effects $[14,15]$. However, this work makes unlikely the assumption according to which a single pathway involving ROS modulation could support all the actions of lycopene, especially on NF $\kappa \mathrm{B}$ (or AP1) activity. This meaning was corroborated by assays using reporter gene placed under the control of $\operatorname{IgK}$ enhancer bearing $\mathrm{NF} \kappa \mathrm{B}$ binding sites; these assays showed that only a low lycopene concentration leads to an enhancement of $\mathrm{TNF} \alpha$-induced reporter gene expression but this effect disappeared in the presence of a higher concentration of lycopene.

It is noteworthy that present experimentation has been performed with "physiological" concentration of lycopene, corresponding to a serum concentration observed following a moderate consumption of this carotenoid. Indeed, in a range of studies, the main concern is about the exact bioactive concentration present in the organism and the real cell bioavailability of this highly lipophilic compound 


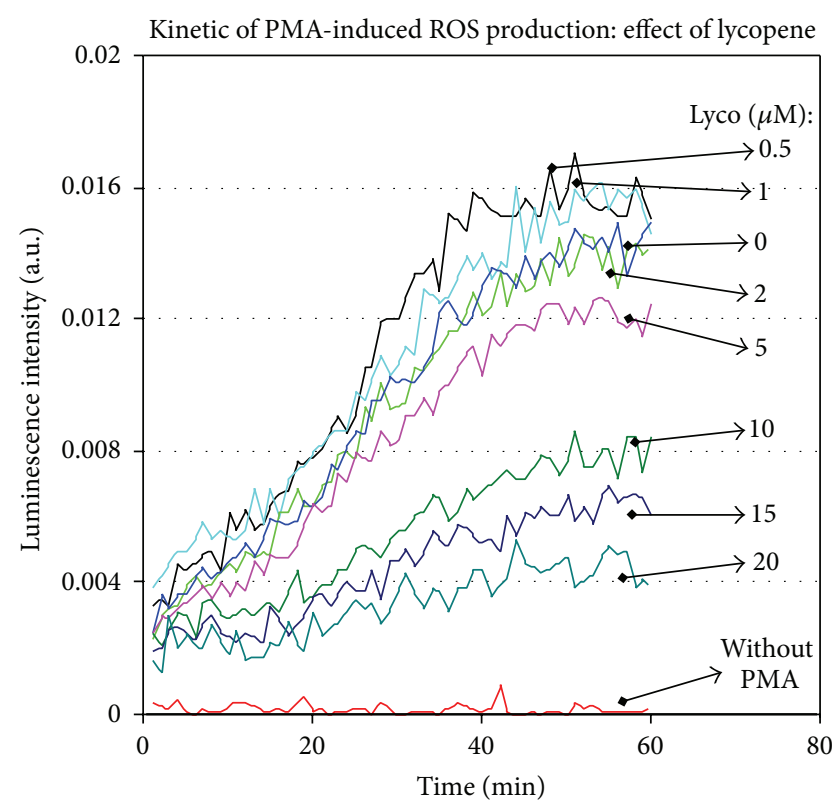

(a)

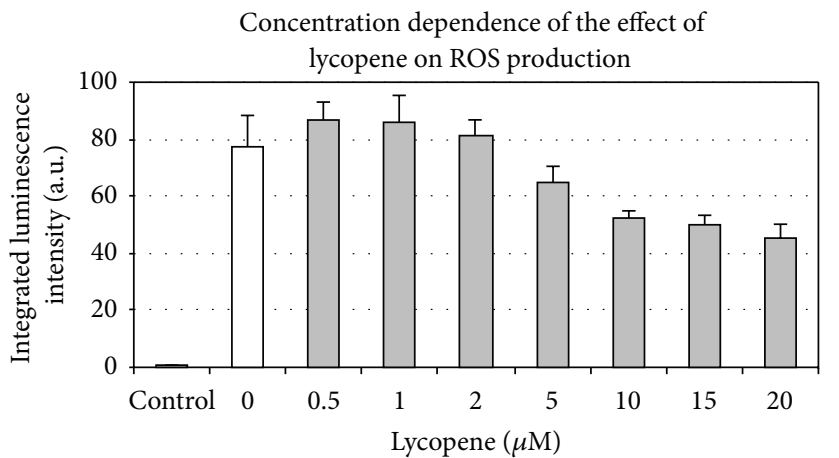

(b)

FIGURE 4: Lycopene modulates PMA-induced ROS production in THP1 cells. THP1 cell suspension was distributed into multiwell plates and, according to the assays, different concentrations of lycopene were added for 2 hours. Then, PMA (100 nM) together with lucigenin was added, and ROS-induced luminescence was immediately recorded for $60 \mathrm{~min}$ (a). Data were collected on computer and kinetics integration was performed (b). A representative experiment is shown. Values are means $\pm \mathrm{SD}(n=8)$.

$[38,39]$ and, in some in vitro studies, the high concentration of lycopene used $(10 \mu \mathrm{M}$ or more) may preclude possible physiological and nutritional interpretations of the results.

The gene induction triggered in Caco2 cells in response to a THP1 cell culture-derived conditioned medium showed that the inflammation induced in immune cells was transferable to epithelial cells. We found that whatever the range of induction is only a certain proportion (around 50\%) of gene expression was found to be reduced in cells pretreated with lycopene, showing that this compound probably modulates only one of the pathways involved in gene induction.

In this work, we have shown that an important yet previously unrecognized second level of regulation could be operative in monocytes. Indeed, MMP9 secretion was modulated in the presence of lycopene, and the c-AMP/PKA system appears to be involved in this process.

A range of observations reported in the literature could support these data. Indeed, it is known that traffic of MMPcontaining vesicles and exocytosis is dependent on microtubules [40] and that c-AMP is known to be involved in various secretion mechanisms via the regulation of exocytosis in many cells [41-44]. Furthermore, it is established that c-AMP controls cell proliferation [45-47] and it has been reported that a moderate activation of cAMP/PKA is sufficient to enhance the chronic inflammation [48]. Finally, adenylate cyclase, c-AMP, and PKA have all been shown to be involved in some of the effects of carotenoids [46, 47].

Cell treatment with lycopene leads to enhanced c-AMP cell content. Given that this enhancement was amplified by the addition of IBMX and that the increase in lycopeneinduced MMP9 activity was prevented by cell cotreatment with an inhibitor of c-AMP production, we concluded that the action of lycopene involved c-AMP synthesis. This interpretation is further supported by our present data showing that compounds known to induce enhanced c-AMP synthesis (dbcAMP and Forskolin) also enhance MMP9 secretion as illustrated by the activity levels found in conditioned media derived from cells treated with these compounds.

What is the mechanism that enables lycopene to induce cAMP synthesis? An answer could involve a mechanism modulating the coupling of adenylate cyclase with G proteins. G proteins tend to cluster in specialized distinct microdomains $[49,50]$ and remain confined to caveolae structures [50]. For example, disassembly of caveolae structure with cyclodextrin led to enhanced c-AMP accumulation in response to $\beta 2$ adrenergic receptor agonists [50]. Thus, the interaction of $\mathrm{G} \alpha$ protein subunits, and adenylate cyclase enzymes, is dampened by the interaction with caveolin protein (cav-1) which is the main constituent of caveolae.

It was reported that carotene at low concentration acted as a growth-inhibiting agent in cav-1-positive cells but not in cav-1-negative cells and regulated the expression of cav-1 protein [50], showing that carotene may modulate cell activity through a mechanism involving cav-1 protein. This modulation could involve disassembly of caveolae structure [50] and consequently enhanced adenylate cyclase and c-AMP level. The fact that caveolin is expressed in THP1 cells makes it possible that, in this cell line, carotenoids worked via a mechanism involving caveolin and c-AMP [51]. 


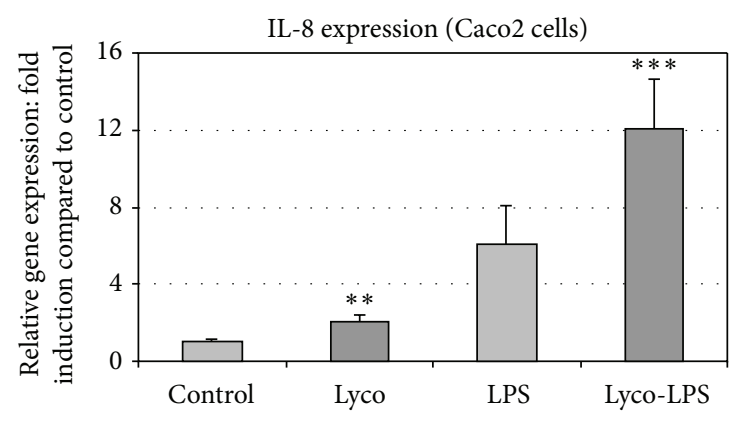

(a)

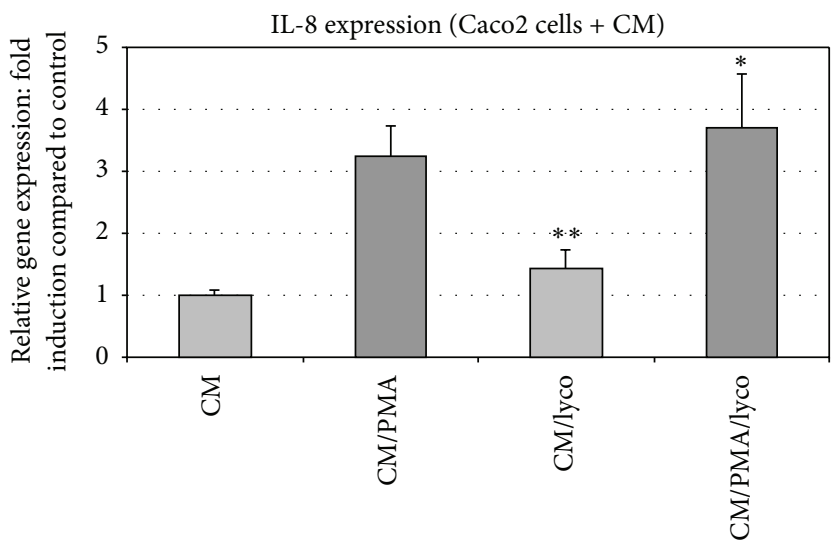

(b)

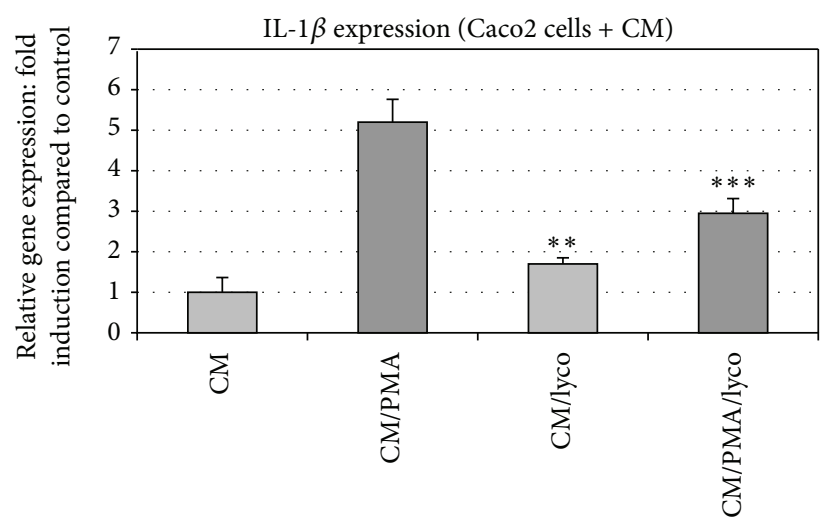

(c)

FIGURE 5: Lycopene-induced modulation of IL-8 and IL-1 gene expression in Caco2 cells. (a) Lycopene induced upregulation of basal and LPSinduced IL-8 gene expression in Caco2 cells. IL-8 gene expression was studied in Caco2 cells treated with LPS. Modulation of this expression was studied in Caco 2 cell cultures pretreated for $2 \mathrm{~h}$ with or without vectorized lycopene. Then, according to assays, LPS (100 ng/mL) was added for $6 \mathrm{~h}$ and mRNA expression was analyzed by RT-qPCR. (b) Lycopene induced no modification of gene expression induced by THP1derived conditioned medium (CM) in Caco2 cells. THP1 cells were or not exposed to PMA for 2 hours. Then, the cell culture medium was discarded and the cells were extensively washed and a fresh medium without PMA was added and culture was resumed for $6 \mathrm{~h}$. At the end of the culture period, the conditioned media (CM) were collected and then added to Caco2 cell cultures pretreated or not with lycopene for $12 \mathrm{~h}$. The final treatment of Caco2 cells with the conditioned medium (CM) was for $6 \mathrm{~h}$ and, finally, expression of inflammatory genes was assessed by qRT-PCR. (c) Lycopene downregulates IL-1 gene expression induced by THP1-derived conditioned medium (CM) in Caco2 cells. THP1 cells were or not exposed to PMA for 2 hours. Then, the cell culture medium was discarded and the cells were extensively washed and a fresh medium without PMA was added and culture was resumed for $6 \mathrm{~h}$. At the end of the culture period, the conditioned media (CM) were collected and then added to Caco 2 cell cultures pretreated or not with lycopene for $12 \mathrm{~h}$. The final treatment of Caco 2 cells with the conditioned medium (CM) was for $6 \mathrm{~h}$ and, finally, expression of inflammatory genes was assessed by qRT-PCR. Values are means \pm SD $(n=8)$. Assays treated with lycopene were compared to corresponding assays without lycopene. ${ }^{* * *} P<0.01 ;{ }^{* *} P<0.05 ; *$, nonsignificantly different.

\section{Conclusions}

The experimental conditions used in this work were aimed at reproducing a proinflammatory state of the intestine during which reactive monocytes are recruited. We conclude that a low carotenoid concentration could modulate physiological and pathological proinflammatory conditions through both transcriptional and nontranscriptional actions, independently of ROS production. This low concentration may influence the enhancement of inflammation induced by a cross talk between epithelial and newly recruited monocytes in the gastrointestinal mucosa.

\section{Conflict of Interests}

The authors declare that there is no conflict of interests regarding the publication of this paper.

\section{Acknowledgments}

This work was supported by the INSERM (French National Institute of Healthcare and Medical Research), the INRA (French National Institute of Agronomics Research), and the CNRS (French National Institute for Scientific Research). The authors thank P. Bremond and S. Barthélémy for their expert 


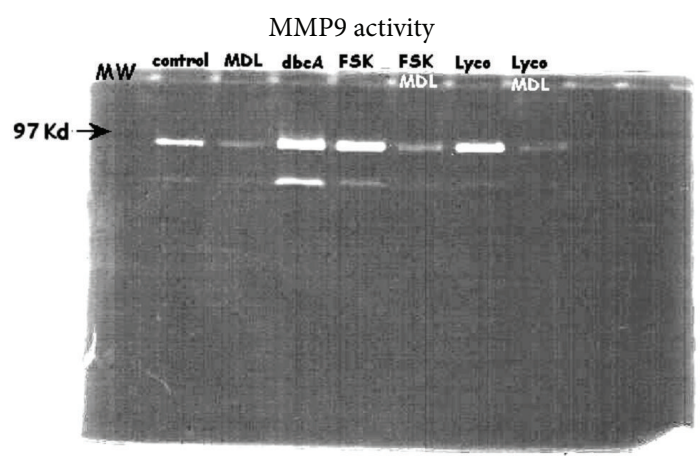

(a)

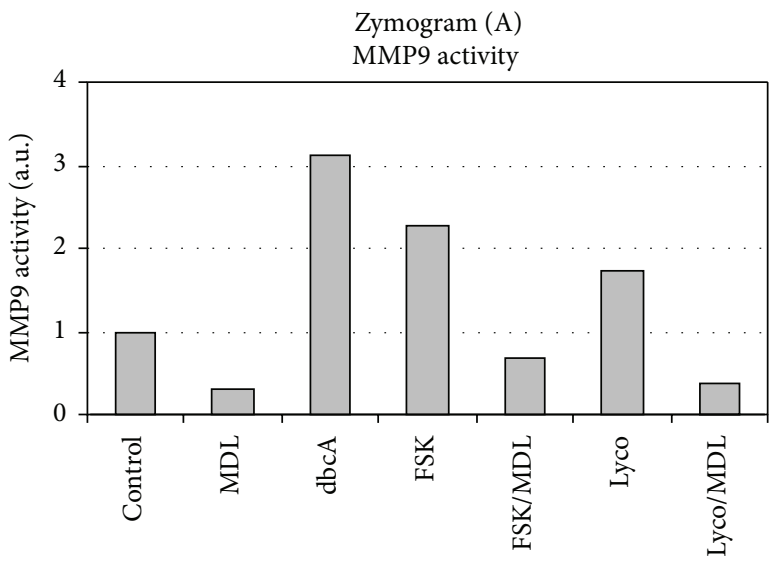

(c)

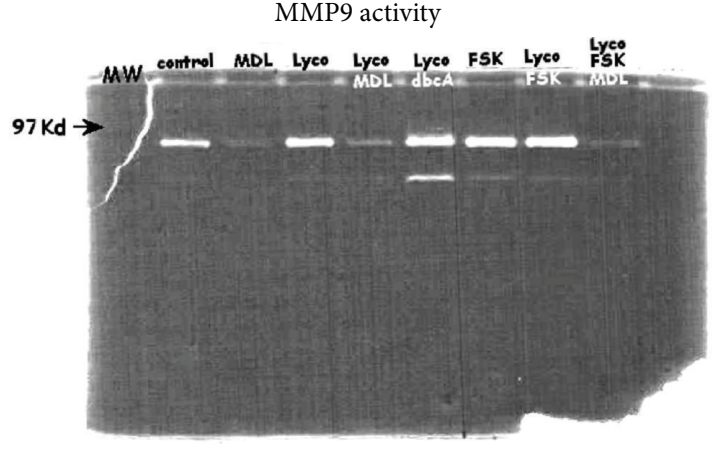

(b)

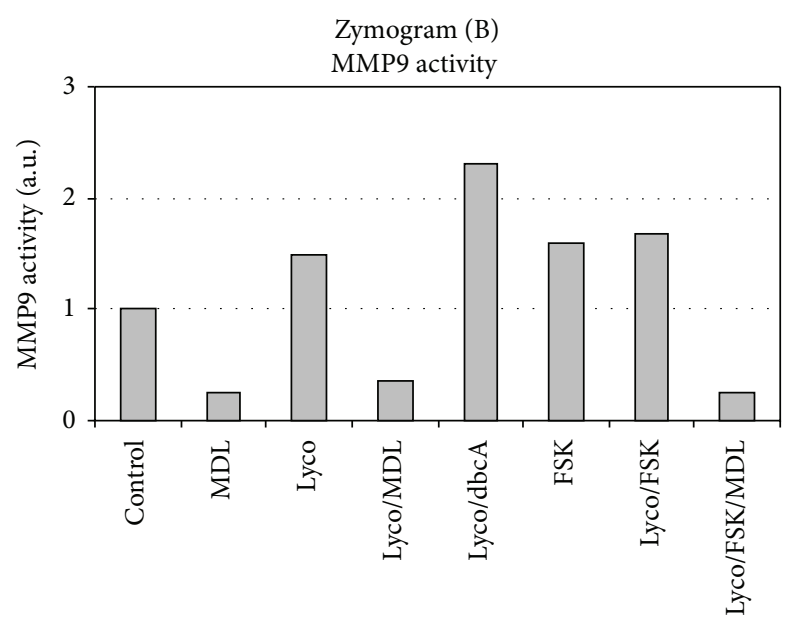

(d)

FIGURE 6: MMP9 activity is induced by lycopene in THP1 cells. THP1 cells were cultured for $12 \mathrm{~h}$ in the presence or not of lycopene ( $2 \mu \mathrm{M})$ together with or without different effectors acting specifically on the c-AMP metabolism (FSK, MDL, and IBMX). Culture medium was collected and zymography ((a), (b)) was performed as described under Materials and Methods. Densitometry analysis of zymograms (A) and (B) was performed and results are reported on graphs (c) and (d), respectively. One representative experiment out of three is shown.

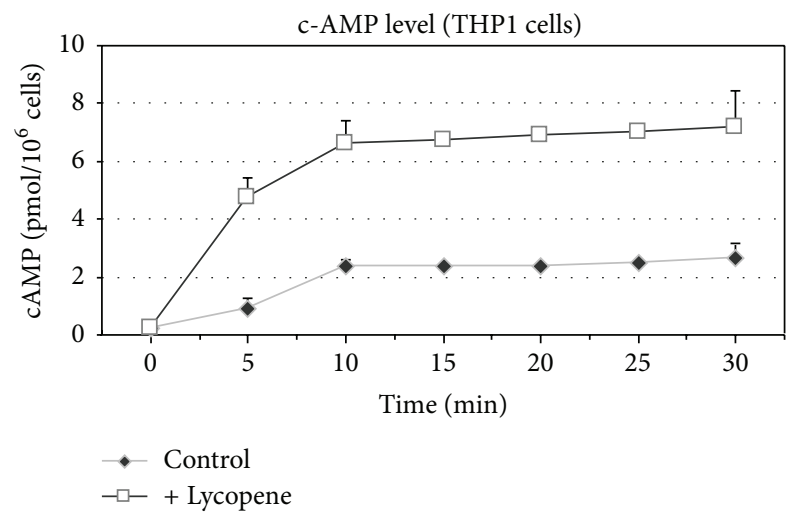

FIGURE 7: Lycopene-induced enhancement of c-AMP level in THP1 cells. THP1 cells were cultured for indicated times in the presence or not of lycopene $(2 \mu \mathrm{M})$. The cells were then harvested and analyzed for c-AMP content as indicated under Materials and Methods. Values are means $\pm \operatorname{SD}(n=6)$.

technical assistance and Dr. Boyd for providing the MMP9derived plasmids.

\section{References}

[1] H. Gerster, "Anticarcinogenic effect of common carotenoids," International Journal for Vitamin and Nutrition Research, vol. 63, no. 2, pp. 93-121, 1993.

[2] G. van Poppel and R. A. Goldbohm, "Epidemiologic evidence for $\beta$-carotene and cancer prevention," The American Journal of Clinical Nutrition, vol. 62, no. 6, supplement, pp. 1393S-1402S, 1995.

[3] ATCB, "The effect of vitamin E and beta carotene on the incidence of lung cancer and other cancers in male smokers," The New England Journal of Medicine, vol. 330, no. 15, pp. 1029-1035, 1994.

[4] K. Canene-Adams, J. K. Campbell, S. Zaripheh, E. H. Jeffery, and J. W. Erdman Jr., "The tomato as a functional food," Journal of Nutrition, vol. 135, no. 5, pp. 1226-1230, 2005.

[5] J. Levy, E. Bosin, B. Feldman et al., "Lycopene is a more potent inhibitor of human cancer cell proliferation than either $\alpha$ carotene or $\beta$-carotene," Nutrition and Cancer, vol. 24, no. 3, pp. 257-266, 1995.

[6] V. Bhuvaneswari and S. Nagini, "Lycopene: a review of its potential as an anticancer agent," Current Medicinal Chemistry-AntiCancer Agents, vol. 5, no. 6, pp. 627-635, 2005. 
[7] N. Chalabi, L. le Corre, J.-C. Maurizis, Y.-J. Bignon, and D. J. Bernard-Gallon, "The effects of lycopene on the proliferation of human breast cells and BRCA1 and BRCA2 gene expression," European Journal of Cancer, vol. 40, no. 11, pp. 1768-1775, 2004.

[8] N. Chalabi, L. Delort, S. Satih, P. Déchelotte, Y.-J. Bignon, and D. J. Bernard-Gallon, "Immunohistochemical expression of RAR $\alpha, \operatorname{RAR} \beta$, and $\mathrm{Cx} 43$ in breast tumor cell lines after treatment with lycopene and correlation with RT-QPCR," Journal of Histochemistry and Cytochemistry, vol. 55, no. 9, pp. 877-883, 2007.

[9] N. Chalabi, L. Delort, L. le Corre, S. Satih, Y. J. Bignon, and D. Bernard-Gallon, "Gene signature of breast cancer cell lines treated with lycopene," Pharmacogenomics, vol. 7, no. 5, pp. 663672, 2006.

[10] R. J. Cousins, "Nutritional regulation of gene expression," The American Journal of Medicine, vol. 106, no. 1A, pp. 20S-23S, 1999.

[11] J. E. Hesketh, M. H. Vasconcelos, and G. Bermano, "Regulatory signals in messenger RNA: determinants of nutrient-gene interaction and metabolic compartmentation," British Journal of Nutrition, vol. 80, no. 4, pp. 307-321, 1998.

[12] L. M. Salati, W. Szeszel-Fedorowicz, H. Tao et al., "Nutritional regulation of mRNA processing," Journal of Nutrition, vol. 134, no. 9, pp. 2437S-2443S, 2004.

[13] W. Stahl, S. Nicolai, K. Briviba et al., "Biological activities of natural and synthetic carotenoids: induction of gap junctional communication and singlet oxygen quenching," Carcinogenesis, vol. 18, no. 1, pp. 89-92, 1997.

[14] L.-X. Zhang, R. V. Cooney, and J. S. Bertram, "Carotenoids upregulate connexin 43 gene expression independent of their provitamin A or antioxidant properties," Cancer Research, vol. 52, no. 20, pp. 5707-5712, 1992.

[15] L.-X. Zhang, R. V. Cooney, and J. S. Bertram, "Carotenoids enhance gap junctional communication and inhibit lipid peroxidation in $\mathrm{C} 3 \mathrm{H} / 10 \mathrm{~T} 1 / 2$ cells: relationship to their cancer chemopreventive action," Carcinogenesis, vol. 12, no. 11, pp. 2109-2114, 1991.

[16] J. S. Bertram, A. Pung, M. Churley, T. J. Kappock IV, L. R. Wilkins, and R. V. Cooney, "Diverse carotenoids protect against chemically induced neoplastic transformation," Carcinogenesis, vol. 12, no. 4, pp. 671-678, 1991.

[17] A. Nahum, K. Hirsch, M. Danilenko et al., "Lycopene inhibition of cell cycle progression in breast and endometrial cancer cells is associated with reduction in cyclin D levels and retention of p27Kip1 in the cyclin E-cdk2 complexes," Oncogene, vol. 20, no. 26, pp. 3428-3436, 2001.

[18] E. Gouranton, G. Aydemir, E. Reynaud et al., "Apo-10' -lycopenoic acid impacts adipose tissue biology via the retinoic acid receptors," Biochimica et Biophysica Acta, vol. 1811, no. 12, pp. 1105-1114, 2011.

[19] E. Gouranton, C. Thabuis, C. Riollet et al., "Lycopene inhibits proinflammatory cytokine and chemokine expression in adipose tissue," Journal of Nutritional Biochemistry, vol. 22, no. 7, pp. 642-648, 2011.

[20] J. Marcotorchino, B. Romier, E. Gouranton et al., "Lycopene attenuates LPS-induced TNF-alpha secretion in macrophages and inflammatory markers in adipocytes exposed to macrophage-conditioned media," Molecular Nutrition \& Food Research, vol. 56, no. 5, pp. 725-732, 2012.

[21] C.-S. Huang, Y.-E. Fan, C.-Y. Lin, and M.-L. Hu, "Lycopene inhibits matrix metalloproteinase- 9 expression and downregulates the binding activity of nuclear factor-kappa $\mathrm{B}$ and stimulatory protein-1," Journal of Nutritional Biochemistry, vol. 18, no. 7, pp. 449-456, 2007.

[22] C. Cellier, J.-P. Cervoni, N. Patey, J.-P. Barbier, and N. Brousse, "Cellular adherence and chronic inflammatory bowel diseases," Gastroenterologie Clinique et Biologique, vol. 21, no. 11, pp. 832 842, 1997.

[23] X. Gan, B. Wong, S. D. Wright, and T.-Q. Cai, "Production of matrix metalloproteinase-9 in CaCO-2 cells in response to inflammatory stimuli," Journal of Interferon and Cytokine Research, vol. 21, no. 2, pp. 93-98, 2001.

[24] K. A. Scott, C. H. Arnott, S. C. Robinson et al., “TNF- $\alpha$ regulates epithelial expression of MMP-9 and integrin $\alpha \mathrm{v} \beta 6$ during tumour promotion. A role for TNF- $\alpha$ in keratinocyte migration?” Oncogene, vol. 23, no. 41, pp. 6954-6966, 2004.

[25] D. Kelly, J. I. Campbell, T. P. King et al., "Commensal anaerobic gut bacteria attenuate inflammation by regulating nuclearcytoplasmic shutting of PPAR- $\gamma$ and ReIA," Nature Immunology, vol. 5, no. 1, pp. 104-112, 2004.

[26] R. Aneja, K. Odoms, K. Dunsmore, T. P. Shanley, and H. R. Wong, "Extracellular heat shock protein-70 induces endotoxin tolerance in THP-1 cells," Journal of Immunology, vol. 177, no. 10, pp. 7184-7192, 2006.

[27] Y.-E. Joo, T. Karrasch, M. Mühlbauer et al., “Tomato lycopene extract prevents lipopolysaccharide-induced NF- $\kappa$ B signaling but worsens dextran sulfate sodium-induced colitis in NFкBEGFP mice," PLoS ONE, vol. 4, no. 2, Article ID e4562, 2009.

[28] R. Reifen, T. Nur, Z. Matas, and Z. Halpern, "Lycopene supplementation attenuates the inflammatory status of colitis in a rat model," International Journal for Vitamin and Nutrition Research, vol. 71, no. 6, pp. 347-351, 2001.

[29] A. Kaulmann, T. Serchi, J. Renaut, L. Hoffmann, and T. Bohn, "Carotenoid exposure of Caco-2 intestinal epithelial cells did not affect selected inflammatory markers but altered their proteomic response," British Journal of Nutrition, vol. 108, no. 6, pp. 963-973, 2012.

[30] H. Auweter, H. Haberkorn, W. Heckmann et al., "Supramolecular structure of precipitated nanosize beta-carotene particles," Angewandte Chemie International Edition, vol. 38, no. 15, pp. 2188-2191, 1999.

[31] R. Gum, H. Wang, E. Lengyel, J. Juarez, and D. Boyd, "Regulation of $92 \mathrm{kDa}$ type IV collagenase expression by the jun aminoterminal kinase- and the extracellular signal-regulated kinase-dependent signaling cascades," Oncogene, vol. 14, no. 12, pp. 1481-1493, 1997.

[32] H. Sato and M. Seiki, "Regulatory mechanism of $92 \mathrm{kDa}$ type IV collagenase gene expression which is associated with invasiveness of tumor cells," Oncogene, vol. 8, no. 2, pp. 395-405, 1993.

[33] S. Vallée, F. Fouchier, P. Brémond, C. Briand, J. Marvaldi, and S. Champion, "Insulin-like growth factor-1 downregulates nuclear factor $\kappa \mathrm{B}$ activation and upregulates interleukin-8 gene expression induced by tumor necrosis factor $\alpha$, Biochemical and Biophysical Research Communications, vol. 305, no. 4, pp. 831839, 2003.

[34] S. Vallee, S. Laforest, F. Fouchier, M. P. Montero, C. Penel, and S. Champion, "Cytokine-induced upregulation of NF- $\kappa$ B, IL-8, and ICAM-1 is dependent on colonic cell polarity: implication for PKCס," Experimental Cell Research, vol. 297, no. 1, pp. 165185, 2004.

[35] F. Fouchier, C. Penel, M. Pierre Montero, P. Bremond, and S. Champion, "Integrin $\alpha \mathrm{v} \beta 6$ mediates HT29-D4 cell adhesion to 
MMP-processed fibrinogen in the presence of Mn2+," European Journal of Cell Biology, vol. 86, no. 3, pp. 143-160, 2007.

[36] A. Kimura, A. Israel, O. le Bail, and P. Kourilsky, "Detailed analysis of the mouse $\mathrm{H}-2 \mathrm{~Kb}$ promoter: enhancer-like sequences and their role in the regulation of class I gene expression," Cell, vol. 44, no. 2, pp. 261-272, 1986.

[37] T. D. Schmittgen and K. J. Livak, "Analyzing real-time PCR data by the comparative CT method," Nature Protocols, vol. 3, no. 6, pp. 1101-1108, 2008.

[38] R. V. Cooney, J. S. Bertram, J. H. Hankin et al., "Relationship between dietary, serum, and tissue levels of carotenoids," Cancer Letters, vol. 61, no. 1, pp. 81-87, 1991.

[39] C. M. Allen, S. J. Schwartz, N. E. Craft, E. L. Giovannucci, V. L. De Groff, and S. K. Clinton, "Changes in plasma and oral mucosal lycopene isomer concentrations in healthy adults consuming standard servings of processed tomato products," Nutrition and Cancer, vol. 47, no. 1, pp. 48-56, 2003.

[40] E.-M. Schnaeker, R. Ossig, T. Ludwig et al., "Microtubuledependent matrix metalloproteinase-2/matrix metalloproteinase- 9 exocytosis: prerequisite in human melanoma cell invasion," Cancer Research, vol. 64, no. 24, pp. 8924-8931, 2004.

[41] G. T. Pearson, J. Singh, and O. H. Petersen, "Adrenergic nervous control of cAMP-mediated amylase secretion in the rat pancreas," The American Journal of Physiology, vol. 246, no. 5, pp. G563-G573, 1984.

[42] X. Wang and R. D. Klein, "Prostaglandin E2 induces vascular endothelial growth factor secretion in prostate cancer cells through EP2 receptor-mediated cAMP pathway," Molecular Carcinogenesis, vol. 46, no. 11, pp. 912-923, 2007.

[43] T. S. Mcquaid, M. C. Saleh, J. W. Joseph et al., "cAMP-mediated signaling normalizes glocuse-stimulated insulin secretion in uncoupling protein- 2 overexpressing $\beta$-cells," Journal of Endocrinology, vol. 190, no. 3, pp. 669-680, 2006.

[44] N. Ozaki, T. Shibasaki, Y. Kashima et al., "cAMP-GEFII is a direct target of cAMP in regulated exocytosis," Nature Cell Biology, vol. 2, no. 11, pp. 805-811, 2000.

[45] P. J. S. Stork and J. M. Schmitt, "Crosstalk between cAMP and MAP kinase signaling in the regulation of cell proliferation," Trends in Cell Biology, vol. 12, no. 6, pp. 258-266, 2002.

[46] M. B. Hazuka, J. Edwards-Prasad, F. Newman, J. J. Kinzie, and K. N. Prasad, " $\beta$-carotene induces morphological differentiation and decreases adenylate cyclase activity in melanoma cells in culture," Journal of the American College of Nutrition, vol. 9, no. 2, pp. 143-149, 1990.

[47] H. A. N. Al-Wadei, M. Majidi, M.-S. Tsao, and H. M. Schuller, "Low concentrations of beta-carotene stimulate the proliferation of human pancreatic duct epithelial cells in a PKAdependent manner," Cancer Genomics and Proteomics, vol. 4, no. 1, pp. 35-42, 2007.

[48] C. Krakstad, A. E. Christensen, and S. O. Døskeland, "cAMP protects neutrophils against TNF- $\alpha$-induced apoptosis by activation of cAMP-dependent protein kinase, independently of exchange protein directly activated by cAMP (Epac)," Journal of Leukocyte Biology, vol. 76, no. 3, pp. 641-647, 2004.

[49] E.-M. Hur and K.-T. Kim, "G protein-coupled receptor signalling and cross-talk: achieving rapidity and specificity," Cellular Signalling, vol. 14, no. 5, pp. 397-405, 2002.

[50] P. Palozza, R. Sestito, N. Picci, P. Lanza, G. Monego, and F. O. Ranelletti, “The sensitivity to $\beta$-carotene growth-inhibitory and proapoptotic effects is regulated by caveolin-1 expression in human colon and prostate cancer cells," Carcinogenesis, vol. 29, no. 11, pp. 2153-2161, 2008.
[51] G. Llaverias, M. Vázquez-Carrera, R. M. Sánchez et al., "Rosiglitazone upregulates caveolin-1 expression in THP-1 cells through a PPAR-dependent mechanism," Journal of Lipid Research, vol. 45, no. 11, pp. 2015-2024, 2004. 


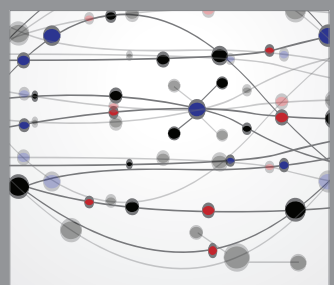

The Scientific World Journal
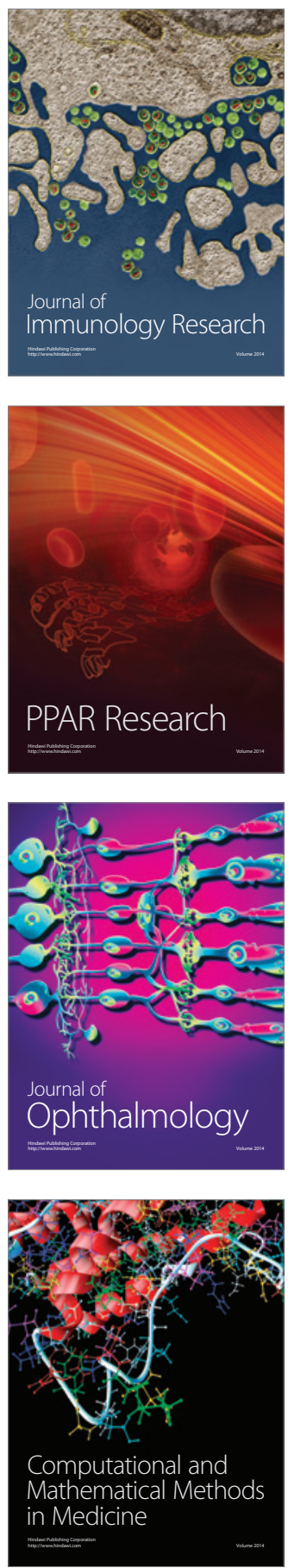

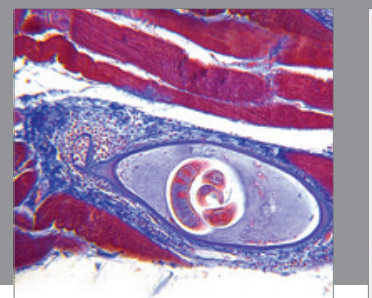

Gastroenterology

Research and Practice
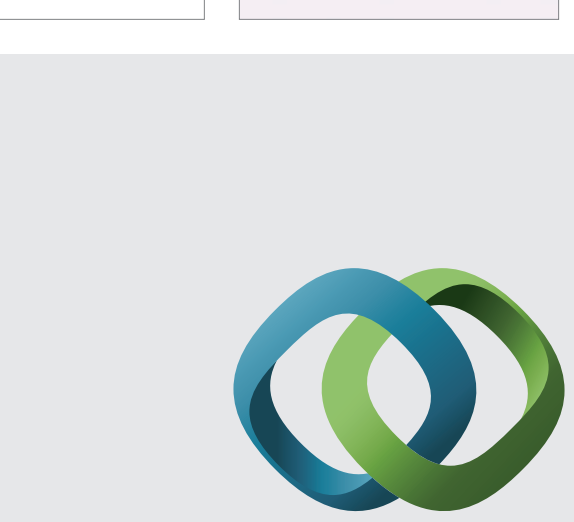

\section{Hindawi}

Submit your manuscripts at

http://www.hindawi.com
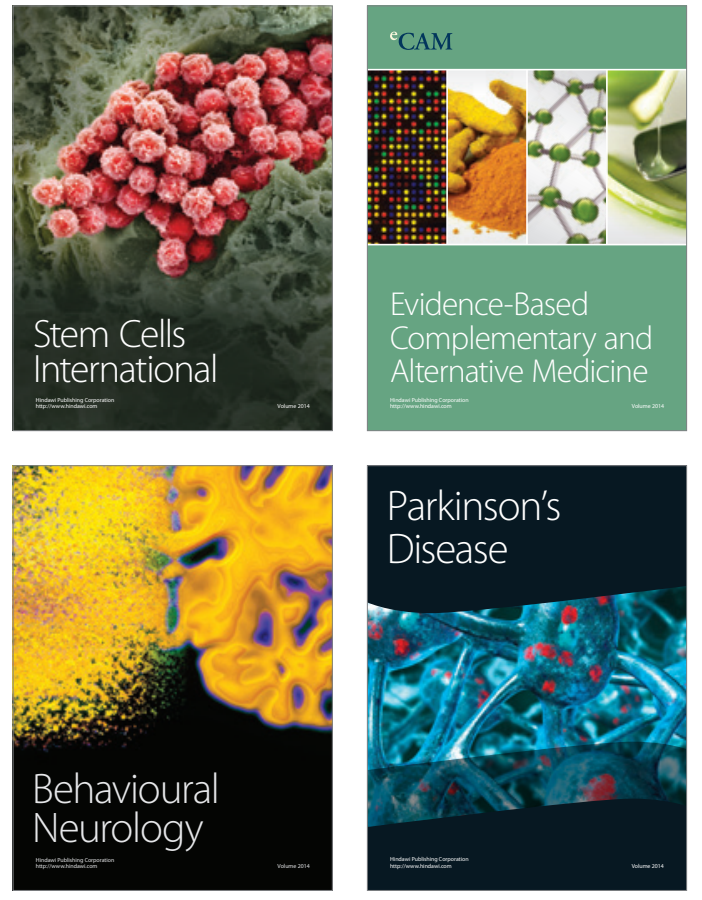
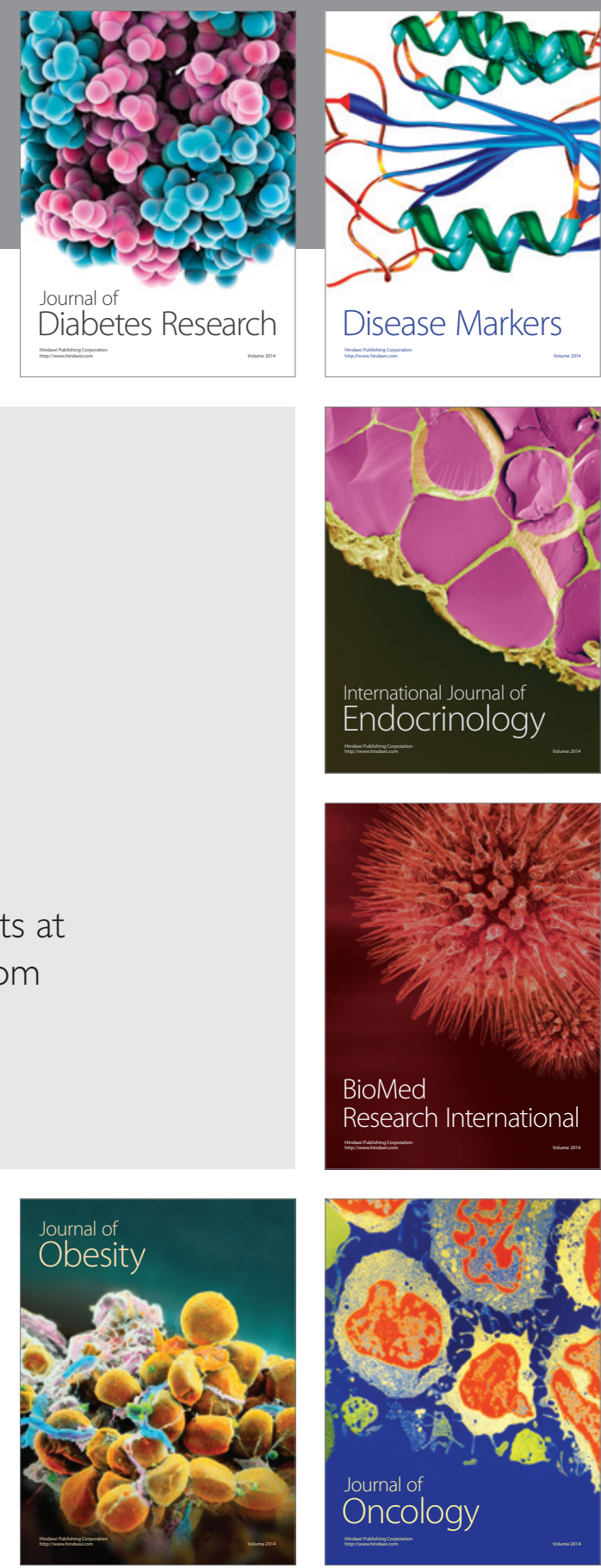

Disease Markers
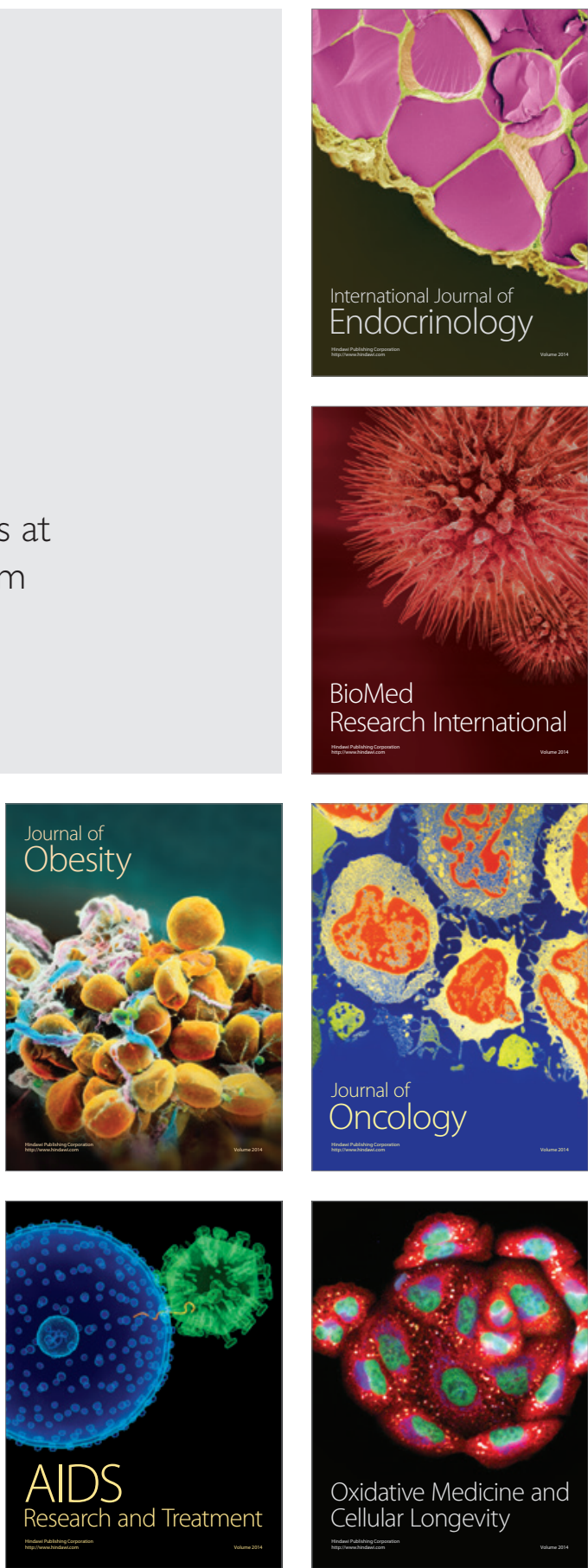